\title{
Time to revisit product placement in films and on television to promote health damaging products
}

\author{
Martin McKee professor of European public health \\ London School of Hygiene and Tropical Medicine, London WC1H 9SH, UK
}

By showing that James Bond may have a drink problem, ${ }^{1}$ Johnson and colleagues have helpfully provided the UK's intelligence and security committee with questions that they can use to avoid, once more, the unpleasant business of actually holding our secret services to account for their actions. ${ }^{2}$

However, an examination of what he drinks is equally of interest. Bond aficionados will have noticed how, in Skyfall, he has abandoned his customary Martini for Heineken beer. They may not be aware that Heineken International paid an estimated $\$ 45 \mathrm{~m}$ ( $£ 27.5 \mathrm{~m} ; € 33 \mathrm{~m}$ ), including associated promotions, for him to do so. ${ }^{3}$ Heineken is clearly confident that it will recoup at least this amount in extra sales. No doubt it has learnt from the tobacco industry, which has long realised the value of product placement, now even more important given bans on traditional advertising. ${ }^{4}$ Crucially, it works, with a wealth of evidence showing that exposure to smoking in films is a powerful determinant of the initiation of smoking in adolescents. ${ }^{5}$
Perhaps it is time for the health select committee to revisit the use of product placement in films and on television to promote health damaging products.

Competing interests: None declared.

1 Johnson G, Guha IN, Davies P. Were James Bond's drinks shaken because of alcohol induced tremor? BMJ 2013;347:f7255. (12 December.)

Bradwell P. Open Rights Group. Intelligence \& security committee fails to convince. 2013. www.openrightsgroup.org/blog/2013/intelligence-security-committee-fails-to-convince.

3 Frost C. Daniel Craig defends "Skyfall" Heineken sponsorship: "the movie cost a lot of money to make." Movifone 2012. http://news.moviefone.com/2012/04/16/daniel-craigskyfall-heineken-sponsor/.

4 Mekemson C, Glantz SA. How the tobacco industry built its relationship with Hollywood. Tob Control 2002;11 (suppl 1):181-91.

5 Charlesworth A, Glantz SA. Smoking in the movies increases adolescent smoking: a review. Pediatrics 2005;116:1516-28.

Cite this as: BMJ 2014;348:g324

๑) BMJ Publishing Group Ltd 2014 